\title{
STRUKTUR HISTOLOGI HATI MENCIT(Mus musculus L.) SETELAH PEMBERIAN EKSTRAK DAUN EKOR NAGA (Rhapidhophora pinnata Schott)
}

\section{LIVER TISSUE STRUCTURE OF MOUSE AFTER TREATMENT WITH Rhapidhophora pinnata Schott LEAF EXTRACTS}

\author{
Ni Komang Tia Pramesti ${ }^{1}$, Ngurah Intan Wiratmini ${ }^{2}$, Ni Putu AdrianiAstiti ${ }^{3}$ \\ Program Studi Biologi, FMIPA, Unud Bukit, Jimbaran, Bali, \\ email : komangbuchkeren@yahoo.com
}

\section{INTISARI}

Daun ekor naga (Rhapidhophora pinnata, Schott ) merupakan tanaman yang sering digunakan sebagai obat tradisional untuk penyakit hipertensi, stroke dan kanker. Tujuan dari penelitian ini adalah untuk mengetahui pengaruh pemberian ekstrak daun ekor naga(Rhapidhophora pinnata, Schott) terhadap struktur histologi hati mencit (Mus musculusL). Penelitian ini menggunakan Rancangan Acak Lengkap (RAL) dengan menggunakan 28 ekor mencit betina yang dibagi menjadi 4 kelompok perlakuan. Kelompok P0 (kontrol) diberikan NaCL dan kelompok P1, P2 dan P3 diberikan ekstrak daun ekor naga dengan dosis berturut-turut 50,100 dan $150 \mathrm{mg} / \mathrm{KgBB}$ selama 14 hari secara oral (gavage). Mencit dibedah pada hari ke-15 untuk diambil hatinya kemudian diamati kerusakan berupa degenerasi lemak, degenerasi hidropis dan nekrosis. Data dianalisis dengan uji Kruskal-Wallis. Hasil analisis menunjukkan tidak terdapat perbedaan nyata antara kelompok kontrol dengan perlakuan terhadap parameter degenerasi lemak, hidropis dan nekrosis, namun ditemukan adanya hemoragi, kongesti dan infiltrasi sel radang.

\section{Kata kunci :Rhapidhophora pinnata Schott,hati, mencit}

\section{ABSTRACT}

Rhapidhophora pinnata, Schott is a traditional medical plant that has been use remedy for treatment of hypertension, stroke. Aims of this research is to determine the effect of Rhapidhophora pinnata Schott leaf extract toward mouse (Mus musculus L) liverhistological structure. This research used completely randomized design with 28 female mice that were divide into 4 groups of $\mathrm{P} 0$ (control) received $0,9 \% \mathrm{NaCl}$, group P1, P2, and $\mathrm{P} 3$ received 50, 100 and 150 $\mathrm{mg} / \mathrm{kg}$ bw respectively by oral administration. The treatment were given daily for 14 days. All of the mice were sacrificed by ether after 15 days. The liver were examined for their histopathological changes, namely fatty degeneration, hydropic degenaration and necrosis. Results were statistically analised by Kruskal-Wallis method. Treatment groups showed no significant differences with regard of liver histopatological changes, however hemorrhage, sinusoid congestion and inflamatory cell infiltration were found in liver.

Keyword : Rhapidhophora pinnata Schott, liver, mice

\section{PENDAHULUAN}

Obat tradisional merupakan obat yang diperoleh dan diolah dari bahan alam seperti tumbuhan, hewan dan mineral atau campuran dari ketiga bahan tersebut namun, di masyarakat bahan alam yang digunakan sebagai obat lebih banyak berasal dari tumbuhan dibandingkanbahan alam lainnya sehingga sebutan obat tradisional lebih identik dengan tanaman obat (Yuliani, 2001).

Tanaman yang digunakan sebagai obat tradisional salah satunya adalah tanamandaun ekor naga (Rhapidhophora pinnata Schott). Tanaman ekor naga merupakan famili dari Araceaeyang dapat digunakan sebagai obat untuk penyakit seperti hipertensi, stroke dan kanker (Makhdalena, 2006). Biasanya masyarakat menggunakan tanaman ekor naga untuk pengobatan dengan cara merebus daunnya (Marteka, 2007). Penelitian lain membuktikan juga bahwa ekstrak daun ekor naga dapat menurunkan kolesterol pada tikus putih jantan (Alen et al., 2006). Lebih jauh Ariantoni (2006), melaporkan bahwa antioksidan yang dikandung dalam daun ekor naga dapat menetralisir dan meredam efek negatif radikal bebas. Selain sebagai tanaman obat, daun ekor naga juga mampu meningkatkan ketebalan endometrium pada mencit betina yang diovariektomi pada dosis optimal 100mg/KgBB (Fernandes, 2015). Namun, penggunaan tanaman sebagaiobat di masyarakatapabila dikonsumsi dalam jangka panjang juga harus diuji keamanannya terhadap organ lain seperti misalnya organ hati.

Hati merupakan organ terbesar yang terletak didalam rongga abdomen di bawah diafragma dan merupakan sel dengan fungsi endokrin, eksokrin, dan mentransfer zat-zat hasil metabolisme ke organ tubuh lain (Junqueiraet al., 1998).Zat dari makanan atau minuman yang masuk ke dalam tubuh kemudian dicerna oleh organ pencernaan untuk direabsorbsi kemudian didetoksifikasi di hati sebagai organ pertama untuk menyaring zat-zat yang masuk tersebut (Gamiswarna et al., 1995). Hati sebagai pendetoksifikasi racun bekerja dengan cara memecah senyawa beracun menjadi beberapa senyawa seperti urea, amonia dan asam urat (Sudatri et al., 2016). Karena fungsinya tersebut maka hati sangat rentan mengalami kerusakan karena zat-zat tosik (Wulandari, 2008). Berdasarkan hal diatas, maka perlu dilakukan penelitian pengaruh ekstrak daun ekor naga (Rhapidhophora pinnata Schott) terhadap struktur histologi hati mencit.

\section{MATERI DAN METODE}

Penelitian ini dilaksanakan pada bulan November 2015 hingga Februari 2016.Pemeliharaan hewan uji dan pemberian perlakuan dilakukan di ruang pemeliharaan hewan coba Jurusan Biologi, FMIPA,Universitas Udayana. Pembuatan preparat histologi hati dilakukan di laboratorium Patologi, Balai Besar Veteriner, Sesetan, 
Denpasar, Bali.Daunekor naga yang diambil adalah daun tua atau berwarna hijau tua yang dipetik daun ke 5 dari ujung daun. Daun tersebut dicuci bersih lalu diiris dan kemudian dikering anginkan pada suhu ruang tanpa paparan sinar matahari sehingga diperoleh berat akhir konstan 500g. Daun ekor naga dihaluskanhinggamenjadi serbuk. Selanjutnya $500 \mathrm{~g}$ serbuk daun ekor naga tersebut dimaserasi dengan alkohol 96\% sebanyak 2 liter selama 24 jam, kemudian disaring dengan kertas saring agar ampas dan ekstrak terpisah.Selanjutnya dievaporasi di Laboratorium Pengembangan Sumber Daya Genetika dan Biologi Molekuler Universitas Udayana denganvacuum ratory evaporator hinga diperoleh crude extract (ekstrak kasar)(Harbone, 1987).Dua puluh delapan ekor mencit dibagi menjadi empat kelompok yaitu kelompok kontrol (P0) yang diberikan $\mathrm{NaCl}$ 0,9\% sedangkan kelompok perlakuan P1, P2 dan P3 diberikan ekstrak daun ekor naga dengan dosis masing-masing $50 \mathrm{mg} / \mathrm{KgBB}$, $100 \mathrm{mg} / \mathrm{KgBB}$ dan $150 \mathrm{mg} / \mathrm{KgBB}$. Ekstrak diberikansebanyak $0,2 \mathrm{ml} /$ ekor/hari setiap satu kali sehari selama 14hari berturut-turut.Hari ke 15 mencit dibedah untuk diambil organ hatinya dan dibuat sayatan histologi kemudian diamati di bawah mikroskop.

Penelitian ini menggunakan Rancangan Acak Lengkap (RAL)dengan 4 perlakuan, setiap perlakuan terdiri dari 7 ulangan (Shaw et al., 2002). Untuk mengamati normalitas distribusi data digunakan uji Kolmogorov-Smirnovkemudian dianalisis dengan Kruskal-Wallis, analisis ini menggunakan program SPSS For Windows versi 22.

\section{HASIL}

Hasil uji statistik organ hati dengan KruskalWallis menunjukkan bahwa pemberian ekstrak daun ekor naga tidak berbeda nyata $(\mathrm{P}>0,05)$ antara kelompok kontrol (P0) dengan perlakuan (P1, P2 dan P3)terhadap kerusakan degenerasi lemak, degenerasi hidropis dan nekrosis pada hati (Tabel 1).

Tabel 1. Hasil analisis dengan uji Kruskal Wallisterhadap degenerasi lemak, degenerasi hidropis dan nekrosis pada hati.

\begin{tabular}{ccccc}
\hline Variabel & Perlakuan & Mean Rank & Chi square & P \\
\hline \multirow{2}{*}{ Degenerasi } & P0 & 9,64 & & \\
lemak & P1 & 12,57 & 6,56 & 0,09 \\
& P2 & 15,43 & & \\
& P3 & 20,36 & & \\
Deg. Hidropis & P0 & 12,36 & & \\
& P1 & 11,43 & 3,13 & \\
& P2 & 16,07 & & 0,56 \\
Nekrosis & P3 & 18,14 & & \\
& P1 & 13,50 & & \\
& P2 & 15,57 & 2,08 & \\
\hline
\end{tabular}

Keterangan: P0 (kontrol), P1 (dosis $50 \mathrm{mg} / \mathrm{kgBB}$ ), P2 (dosis $100 \mathrm{mg} / \mathrm{KgBB}$ ) dan P3 (dosis $150 \mathrm{mg} / \mathrm{KgBB}$ ).

Pemeriksaan secara histologi hati mencit yang diberikan ekstrak daun ekor naga menunjukkan dibeberapa bagian mengalami hemoragi, kongesti dan infiltrasi sel radang pada perlakuan P1, P2 dan P3 seperti pada Gambar 1.
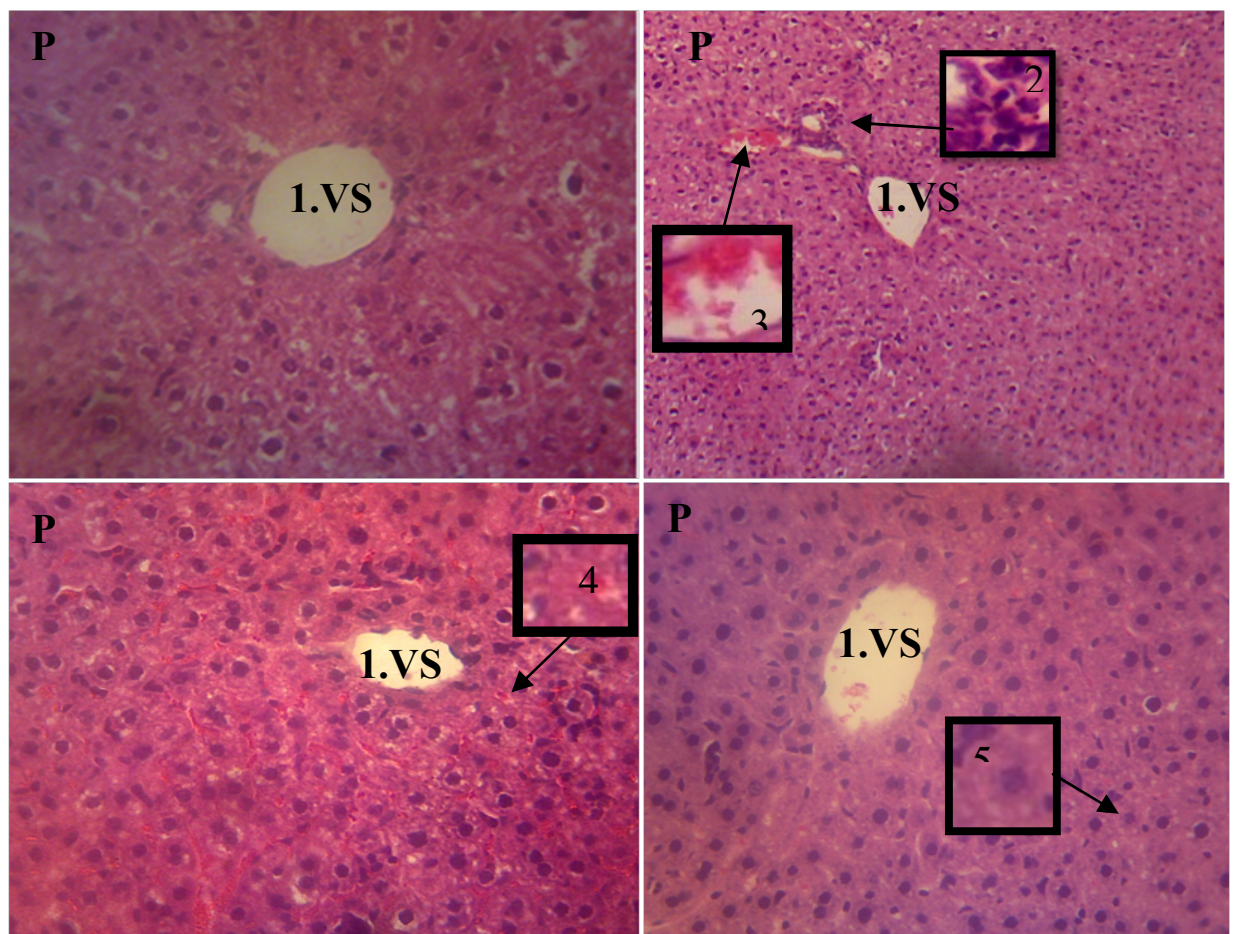

Gambar 1. Struktur histologi hati mencit setelah pemberian ekstrak daun ekor naga.

Keterangan: 1.Vena sentralis, 2.Infiltrasi sel radang, 3.Hemoragi, 4. Kongesti 5. Inti Piknotik P0 (kontrol), P1 (dosis 50 mg/KgBB), P2 (dosis 100 mg/KgBB) dan P3 (dosis150mg/KgBB) 


\section{PEMBAHASAN}

Pemberian ekstrak daun ekor naga terhadap hati menunjukkan tidak ada perbedaan nyata antara kontrol dengan perlakuan. Pemberian ekstrak daun ekor naga pada kelompok perlakuan tidak menyebabkan terjadinya kerusakan degenerasi lemak dan hidropis serta nekrosis pada hati. Hal ini mengindikasikan bahwa pemberian ekstrakdaun ekor naga tidak mengganggu metabolisme lemak di hati sehingga tidak terjadi degenerasi lemak dan hidropis serta nekrosis (nilai $\mathrm{P}>0,05$ ).

Hati merupakan organ ekskresi yang berfungsi untuk mendetoksifikasi zat-zat toksik sehingga adanya kerusakan hati merupakan petunjuk apakah suatu zat itu bersifat toksik atau tidak(Leeet al., 2006).Jika hati terus menerus terpapar obat dan zat kimia dalam jangka panjang maka sel-sel pada hati dapat mengalami perubahan terutama pada sel hepatosit seperti degenerasi lemak dan nekrosis yang dapat menurunkan kemampuan regenerasi sel sehingga menyebabkan kerusakan permanen sampai kematian sel (Anggraeny et al., 2014). Namun dalam penelitian ini hasil statistik menunjukkan tidak berbeda nyata antara kelompok kontrol dengan perlakuan, hal ini berarti pemberian ekstrak daun ekor naga tidak mengganggu metabolisme lemak di hati sehingga tidak terjadi degenerasi lemak, dan hidropis serta nekrosis. Tidak ditemukannya sel hati yang mengalami degenerasi hidropis diduga pemberian ekstrak daun ekor naga tidak menyebabkan akumulasi cairan di dalam sel karena degenerasi hidropis disebabkan oleh adanya

akumulasi cairan akibat kegagalan sel dalam memper tahankan homeostasis (Underwood, 1992). Degenerasi lemak dan degenerasi hidropis merupakan kerusakan sel yang terjadi karena adanya jejas sel yang sifatnya reversible tetapi apabila sel-sel yang mengalami degenerasi lemak dan degenerasi hidropis tidak dapat memperbaiki dirinya maka dapat berakibat pada nekrosis (Suyanti, 2008). Namun dalam penelitian ini tidak ditemukan nekrosis karena tidak ditemukan adanya degenerasi lemak dan hidropis. Menurut Rianah (2014), sel-sel hati dapat memperbaiki dirinya secara fisiologis dan menggantikannya dengan sel baru ketika terjadi suatu kerusakan yang sifatnya reversible sehingga dalam penelitian ini kemungkinan terjadi proses regenerasi sel hati dengan baik.

Meskipun secara statistik tidak ada perbedaan nyata terhadap kerusakan degenerasi lemak dan hidropis serta nekrosis pada hati dalam penelitian ini, pada semua kelompok perlakuan ditemukan kongesti, hemoragi dan infiltrasi sel radang.Hemoragi merupakan kondisi dimana keluarnya darah dari pembuluh darah akibat rusaknya dinding pembuluh darah yang disebabkan oleh karena trauma (kerusakan fisik jaringan yang diakibatkan oleh benturan), infeksi virus dan zat toksik yang menyebabkan dinding vaskula rentan bocor (Putra, 2014). Hemoragi adalah tahap lanjutan dari kongesti yang terjadi karena sinusoid kehilangan kemampuan untuk membendung darah yang mengakibatkan pembuluh darah di sinusoid renggang dan akhirnya pecah (Sudiono, 2003). Sejalan dengan penelitian yang dilaporkan oleh Diwan et al. (2000), bahwa senyawa saponin dapat menyebabkan hemoragi dengan pemberian dosis bertingkat, hemoragi yang terjadi pada hati dalam penelitian ini diduga karena senyawa saponin yang dikandung dalam ekstrak daun ekor naga. Adanya infiltrasi sel radang pada sayatan histologi hati kelompok perlakuan kemungkinan merupakan respon sel terhadap suatu agen patogen seperti bakteri. Pernyataan ini didukung oleh Lukistyowati (2012), bahwa infiltrasi sel radang merupakan pertahanan sel terhadap patogen yang dapat membahayakan sel. Hal ini didukung juga oleh pendapat Thomson, (1984) bahwa infiltrasi sel radang merupakan respon terhadap penyakit atau agen toksik. Lebih jauh Baratawijaya (2002), juga melaporkan bahwa infiltrasi sel radang juga merupakan suatu respon protektif untuk mempertahankan struktur dan memperbaiki fungsi jaringan.

\section{SIMPULAN}

Pemberian ekstrak daun ekor naga (Rhapidhophora pinnata Schott) dengan dosis bertingkat $(50 \mathrm{mg} / \mathrm{KgBB}$, $100 \mathrm{mg} / \mathrm{KgBB}$ dan $150 \mathrm{mg} / \mathrm{KgBB}$ ) tidak menyebabkan kerusakan pada sel-sel hati mencit tetapi menyebabkan hemoragi, kongesti dan infiltrasi sel radang.

\section{UCAPAN TERIMA KASIH}

Ucapan terimakasih kepada seluruh pihak yang telah membantu dalam penelitian ini terutama kepada Ibu Ngurah Intan Wiratmini, Ibu Adriani Astiti, Ibu Iriani Setyawati, Ibu Ni Gusti Ayu Manik Ermayanti dan Bapak I Wayan Kasa atas kritik dan saran yang membangun dalam penulisan ini.

\section{KEPUSTAKAAN}

Alen, Y.S., Makhdalena dan Suharti.2006.Efek Ekstrak Etanol Daun Ekor Naga (Epripemnopsis media) Terhadap Kadar Kolesterol.Prosiding Seminar FMIPA Universitas Andalas.

Anggraeny, E., Tjdanrakirana dan Nur Ducha.2014. Pengaruh Pemberian Filtrat Tauge Kacang Hijau terhadap Histologi Hepar MencitYang Terpapar MSG.Jurnal Lenterabio. 3(3): 186-191.

Ariantoni.2006.Uji Efek Antikanker Ekstrak Etanol Daun Ekor Naga (Epripemnopsis media) pada Mencit Putih Jantan Dengan Metode Micronucleus Assay.Universitas Andalas. (Skripsi).

Baratawijaya,K.G.2002. Imunologi DasarEdisi 5.Jakarta:Penerbit FKUI

Diwan, F.H., I.A., Abdel-Hassan, and S.T., Mohammed. 2000. Effect of Saponin on Mortality and Histopathological Changes in Mice. Eastern Mediterranean Health Journal. 6(23):345-351.

Fernandez,M.A.M.,N.I.Wiratmini dan N.G.A.M. Ermaya nti.2015.Pengaruh Pemberian Ekstrak Daun Ekor Na ga (Rhapidhophora pinnata Schott)

Terhadap Perkembangan Uterus Mencit (Mus muscul us) Yang Diovariektomi.Jurnal Biologi.19(2):74-79.

Guyton, A.C., dan J.E. Hall. 2006. Textbook of Medical Physiology. 11th ed. 
Harborne, J.B. 1987. Metode Fitokimia. Penerbit ITB. Bandung.Junqueira,L.C., J.Carneiro dan R.O Kelley .1998. Histologi Dasar. Terjemahan Tambayong. EGC. Jakarta.

Lee, T.A., B.H. Sci., and Counsel. 2006. The Food From Hell Food Colouring. The Internet Journal of Toxicology. 2(2): 101-110.

Lukistyowati, I.2012. Studi Efektifitas Sambiloto (Andrographis paniculata Ness) Untuk Mencegah Penyakit Edwardsiellosis pada Ikan Patin (Pangius hypopthalmus). Jurnal Berkala Perikanan.40(2): 56-74.

Makhdalena.2006.Efek Ekstrak Etanol Daun Ekor Naga (Eprimnopsis media (Z\&L) Engl.Terhadap Kadar Kolesterol dan Trigliserida Darah Tikus Putih Jantan. Universitas Andalas. (Skripsi).

Marteka, D.2007. Isolasi Senyawa Antioksidan Dari Daun Tumbuhan Ekor Naga (Epripemnopsis media).Universitas Andalas.(Skripsi).

Putra,D.A.2014.Perubahan Struktur Morfologi dan Gambaran Mikroanatomi Insang Ikan Lele(Clarias batrachus) Akibat Paparan Limbah Cair Batik. Jurusan Biologi FMIPA Universitas Negeri Malang.(Skripsi).

Rianah, E.2014.Vitamin C Mencegah Nekrosis dan Gangguan Fungsi Hati yang Disebabkan Oleh Paracetamol Dosis Toksik Pada Mencit (Mus musculus L).Universitas Udayana. (Skripsi).

Shaw, R., M.F.W. Festing., I. Peers and L. Furlong. 2002. The Use of Factoria Designs to Optimize Animal Experiments and Reduce Animal Use. Internationa Laboratory Animal Research Journal. 43(4): 223232.

Sudatri, I.W., I. Setyawati., N.M Suartini dan D.A Yulihastuti. 2016. Penurunan Fungsi Hati Tikus Betina (Rattus Norvegivus L) Yang Diinjeksi White Vitamin C Dosis Tinggi Dalam Jangka Waktu Lama Ditinjau Dari Kadar SGPT, SGOT Serta Gambaran Histologi Hati. Jurnal Metamorfosis. 3 (1): 44-51.

Sudiono, J.B., Kurniadhi, A. Hendrawan dan B. Djinantoro.2003. Ilmu Patologi. EGC.Jakarta

Thomson,R.G.1984.Special Veterinary Pathology.Department of Pathology and Microbiology Atlantic Veterinary College.B.C Decker Inc.Philadelphia.

Underwood, J.C.E. 1992. General and Systemics Patholo gy. Churchil Livingstone. New York.

Wulandari, R. 2008. Pengaruh Penambahan Yeast pada Pemberian Lamtoro Merah (Acacia villosa) terhadap Histopatologi Hati Tikus. Fakultas
Kedokteran Hewan Institut Pertanian Bogor. (Skripsi).

Yuliani, S. 2001. Prospek Pengembangan Obat Tradisional Menjadi Obat Fitofarmaka.Jurnal Litbang Pertanian.Balai Penelitian Tanaman Rempah dan Obat.3(1): 56-72. 